\section{SCREENING EXAMINATION FOR PREVALENCE OF RUBELLA IN WOMEN OF REPRODUCTIVE AGE IN ARMENIA}

\author{
Z.K. Janibekyan \\ Health, Jinishian Memorial Foundation, \\ Yerevan, Armenia
}

Aim: The rubella is mostly dangerous for pregnant women. Depending on the period of pregnancy, when the infection proceeds, a lot of defects and deficiencies are formed to fetus. A task was put to do screening examination of women of reproductive age, living in Armenia, including pregnant women, in order to find out immunity status of Armenian population to rubella.

Methods: Only 2223 women of reproductive age took part in the examination to find immune protein of IgM and IgG classes in blood serum. 2004 women passed screening examination at first group, from those 188 were pregnant women which are the second group. The third group, that consists of 219 women, who have pregnancy complications or have had problems during last pregnancies. The antibodies' titer to the Rubella virus in blood serum was defined by test system Immune Comb Rubella IgG (sensibility -92,6\%) and Immune Comb Rubella IgM (sensibility-95,0\%) Organics" Israel .

Results: The screening examination showed that $13 \%$ women of reproductive age were either infected (primary infection or reinfection) or didn't have enough immunity to rubella virus.

The results of laboratory examination of pregnant women with complications of pregnancy (now or in the past) showed that $6,4 \%$ of women had proceed rubella either as a result of primary infection or reinfection.

Conclusion: It is necessary to realize control over children, whose mothers have preceded rubella in period of pregnancy. This is connected with preventive measures of inborn rubella and consequently, with the birth of healthy children.

\section{UNDERESTIMATION OF INFLUENZA VIRAL INFECTION IN CHILDHOOD ASTHMA EXACERBATIONS}

\author{
A. Mandelcwajg ${ }^{1}$, F. Moulin ${ }^{1}$, C. Menager ${ }^{1}$, \\ F. Rozenberg ${ }^{2}$, P. Lebon ${ }^{2}$, D. Gendrel ${ }^{1}$ \\ ${ }^{1}$ Emergency Room, Saint Vincent de Paul Hospital, \\ ${ }^{2}$ Virology Unit, APHP, Hospital Saint Vincent de \\ Paul, Paris V Descartes, Paris, France
}

Background: Respiratory viruses, including influenza, bocavirus and respiratory syncytial are common agents of acute asthma exacerbation in children

Objective of the study: To compare the incidence of influenza and other respiratory viruses in ambulatory and hospitalized children with asthma exacerbation

Patients and methods: From November 2005 to May 2009, viral immunofluorescence and bocavirus PCR were performed on nasopharyngeal aspirates in children (2-15y) examined in an hospital emergency room for acute asthma attack during the winter seasons and hospitalised or not..

Results: Bocavirus was found in $11.6 \%$ of hospitalized and $13 \%$ of ambulatory patients with exacerbation of asthma, and respiratory syncytial virus in $13.5 \%$ and $17.7 \%$, respectively. However, influenza A virus was detected in $2.6 \%$ of hospitalized and $14.1 \%(p<.001)$ of ambulatorytreated patients.

Conclusion: Influenza virus contributes to exacerbation of childhood asthma and is more often founded in ambulatory patients than in hospitalised, but other respiratory viruses had the same frequency in the two groups. The influenza burden in childhood asthma may be underestimated if only hospitalised patients are considered. 